\title{
A review paper on artificial intelligence at the service of human resources management
}

\author{
Siham Berhil ${ }^{1}$, Habib Benlahmar ${ }^{2}$, Nasser Labani ${ }^{3}$ \\ ${ }^{1,3}$ Department of Mathematics and Computer Science, Faculty of Sciences, Morocco, \\ ${ }^{2}$ Department of Mathematics and Computer Science, Faculty of Sciences Ben Msik, Morocco
}

\begin{tabular}{l} 
Article Info \\
\hline Article history: \\
Received Aug 1, 2019 \\
Revised Oct 2, 2019 \\
Accepted Oct 16, 2019 \\
\hline
\end{tabular}

Keywords:

Artificial intelligence

HR analytics

HR issues

HR risks

Human resources problems

\begin{abstract}
In the last few years, all companies have been interested in the analysis of data related to Human Resources and have focused on human capital, which is considered as the major factor influencing the company's development and all its activities at all levels of human resource policies. Data analysis (HR analytics) will significantly improve business profitability over the next years. We started with an extensive survey of different human resources problems and risks reported by HR specialists, then a comprehensive review of recent research efforts on computer science techniques proposed to solve these problems and finally focusing on suggested artificial intelligence methods. This review article will be an archive and a reference for computer scientists working on HR by summarizing the IT solutions already made in human resources for the period between 2008 and 2018. It aims to present clearly the issues that HR researchers face and for which computer scientists seek solutions. It summarizes at the same time the recent and different methods, IT approaches and tools already used by highlighting those using artificial intelligence.
\end{abstract}

Copyright $\odot 2020$ Institute of Advanced Engineering and Science. All rights reserved.

\section{Corresponding Author:}

Siham Berhil,

Department of Mathematics and Computer Science,

Faculty of Science, El Jadida, Morocco.

Email: sihamberhil@gmail.com

\section{INTRODUCTION}

Human Resources Management has undergone profound transformations as a result of a diversification of issues related to the HR function and a strengthening of its influence in the strategic decision-making processes of companies. Today, the HR function is moving more and more towards personalizing HR practices that take into account the specificities of each target. The goal is to help managers achieve a better intergenerational collaboration. Human Resources Analysis enables companies to make good use of their "employee" databases in order to make the best decisions and improve their operational performance $[1,2]$.

At a time when business leaders are preparing for a digital world that is gaining momentum, artificial intelligence based on the "machine learning" technology [3] promises to revolutionize human resources departments at different levels: recruitment, training, management of career, mobility, compensation and benefits in order to attract talent and high potential, treat and evaluate nominations as quickly as possible, check the suitability of the profile and position and predict the candidate's added value for the company, these are the major challenges of any Human Resources Department[4].

One of the most difficult situations of any company that wants to be modern and competitive is to lose one or more of its successful employees to one of its competitors [5]. Thanks to artificial intelligence, HRDs can implement performance indicators of their human capital, based on internal data analysis, crossreferenced with external market data and in particular competition. The results of these analyses will make it 
possible to map the existing profiles according to each employee's productivity and effectiveness [6-9]. Inspired by the functioning of the human brain, this technology is the subject of a technological boom and it is increasingly bringing about convincing results in the giants of technology (Apple, Facebook, Google, Microsoft ...).

The treatment of the data is an intelligence that must be interpreted, mastered to make the best of it. And it is on the basis of this reflection and on its intuition that the HR function will be able to capitalize and to place its function at a higher strategic and decisional level. Some may think that data and algorithms could be a substitute for the intelligence of their decision when in fact; they allow a better expression of this intelligence. It is fundamental to understand that if data becomes unavoidable, it is not independent. All its value lies in the reading and interpretation of this information by human intelligence. Data does not replace the intelligence and courage of HR; it is at their service. HR, supported by the data, has the means to build their future. Challenging ready-made representations and preconceived ideas to induce propositions based on these observations is the challenge that accompanies the taming of data by HR [10].

\section{LITERATURE SURVEY}

Over the last years, there have been some researchers who have completed their work successfully on Human resources analytics. We have chosen to collect the various researches on this subject during the period between 2008 until 2018. The majority of articles dealing with topics related to the field of artificial intelligence and human resources were published in newspapers from 2015 to 2018, especially between 2015 and 2017. In 2018, the number of researches involved increased between the months of March until September and during the month of November.

Hundreds of articles have appeared in scientific journals related to computer science such as (Future Generation Computer Systems, International Journal of Interactive Multimedia and Artificial Intelligence, International Journal of Computing and Informatics, The Scientific World Journal, ... etc) while others have appeared in human resources management journals (for example: Management : Journal of Contemporary Management Issues, Journal of Business Strategy, Business Horizons, ... etc). Exponential growth of HR articles number from 2008 to 2018 as shown in Figure 1.

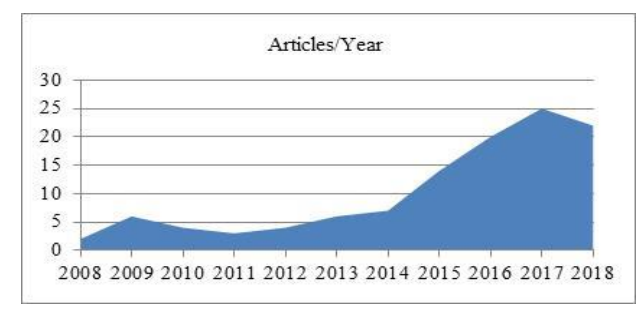

Figure 1. Exponential growth of HR articles number from 2008 to 2018

\section{HUMAN RESOURCES RISKS} in Figure 2.

To achieve these HR goals several risks are arise $[8,11,12,69]$. Human Resources risks as shown

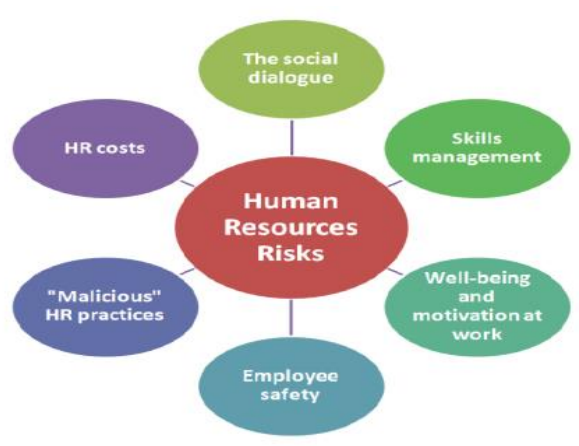

Figure 2. Human resources risks 


\subsection{The Social Dialogue:}

A failure in the management of social dialogue following a lack of communication or precision of managerial objectives can generate strong tensions within the company: prolonged strike (absenteeism, demotivation, lack of trust between managers and employees ...).

Predict: Strike Extra / Absenteeism Rate [13].

\subsection{Skills Management:}

A lack of follow-up of the skills and talents of the company systematically leads to an accentuated departure of key employees of the company: increased demotivation of staff, lack of training, and stagnation of teams...

Predict: attrition rate / assisted awareness rate [14-18].

\subsection{Well-Being and Motivation at Work:}

Some managerial practices such as the setting of unattainable goals and the lack of communication between managers and employees can be considered as a trigger for stress, burn out or even suicide of employees.

Predict: Staff Satisfaction / Staff Involvement [19-21].

\subsection{Employee Safety:}

A lack of formalization of safety procedures and the absence of internal control in this area may lead the company to possible civil and / or criminal penalties following injuries or even deaths in the workplace (degradation of his image).

Predict: Operational risks related to the activity of the company [22].

\section{5. "Malicious" HR Practices:}

A calamitous social climate may be the result of an unsensitized management system based on excessive pressure on the part of management ( pressure on objectives) and lack of control of managerial practices internally (harassment of staff, unequal treatment of situations).

Predict: Indicators to assess the social climate [23].

\subsection{HR Costs:}

A lack of control of HR costs may lead to additional costs and a structural increase in management costs, especially in the absence of management and HR management control: poor management of payroll, cost health insurance / provident insurance. The IT solutions for human resources issues as shown in Table 1. Predict: Indicators to control HR costs and enhanced HR management control [24].

Table 1. The IT Solutions for Human Resources Issues

\begin{tabular}{|c|c|c|}
\hline HR Risks & Problem & Prediction \\
\hline The social dialogue & $\begin{array}{l}\text { Absenteeism, demotivation, lack of trust between } \\
\text { managers and employees... }\end{array}$ & Strike Extra/Absenteeism Rate \\
\hline Skills management & $\begin{array}{l}\text { Demotivation of staff, lack of training, and stagnation of } \\
\text { teams... }\end{array}$ & Attrition rate/assisted awareness rate \\
\hline $\begin{array}{l}\text { Well-being and motivation } \\
\text { at work }\end{array}$ & Stress, burn out or even suicide of employees & Staff Satisfaction/Staff Involvement \\
\hline Employee safety & $\begin{array}{l}\text { civil and/or criminal penalties following injuries or even } \\
\text { deaths in the workplace (degradation of his image) }\end{array}$ & $\begin{array}{l}\text { Operational risks related to the activity of the } \\
\text { company }\end{array}$ \\
\hline $\begin{array}{l}\text { "Malicious" } \\
\text { HR practices }\end{array}$ & harassment of staff, unequal treatment of situations & Indicators to assess the social climate \\
\hline HR costs & $\begin{array}{l}\text { poor management of payroll, cost health insurance/ } \\
\text { provident insurance }\end{array}$ & $\begin{array}{l}\text { Indicators to control HR costs and enhanced HR } \\
\text { management control }\end{array}$ \\
\hline
\end{tabular}

\section{IT SOLUTIONS AND ARTIFICIAL INTELLIGENCE FOR HUMAN RESOURCES PROBLEMS}

\subsection{The Different HR Issues Studied}

According to our research, several HR issues have been asked to computer scientists to find the best possible solutions; most of the issues raised are concerning: Jobs, talents and skills management, candidature/ staff selection and recruitment, attrition, turnover, future human capital needs, HR performance and effectiveness, etc. The following graph shows the important HR issues raised and for which computer scientists have proposed different IT solutions. The important HR issues studied using IT solutions as shown Figure 3. 


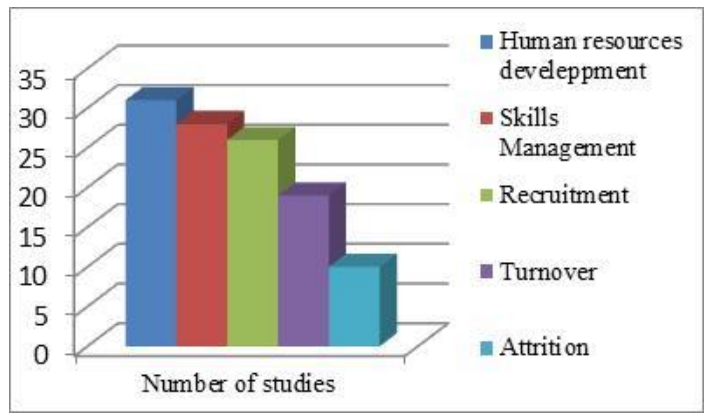

Figure 3. The important HR issues studied using IT solutions

According to the chart, most of the articles found concern HR development, followed by skills management, recruitment and turnover and attritions.

\subsection{IT Solutions for Human Resources Issues}

According to our quantitative research, several IT solutions have been proposed to solve the various problems related to human resources. Percentage of Use of IT solutions for HR issues as shown in Figure 4.

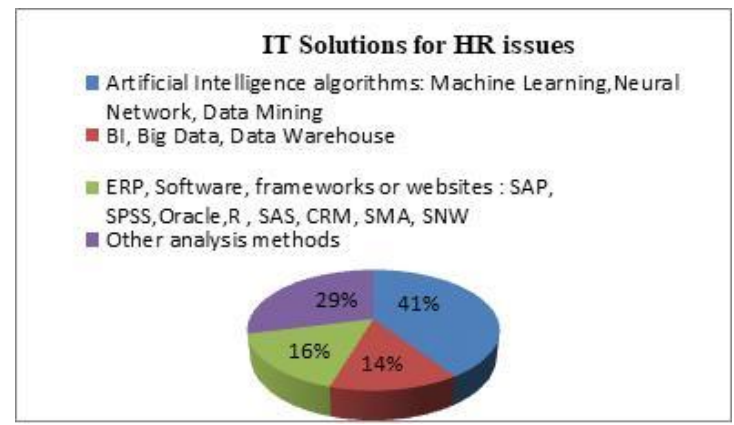

Figure 4. Percentage of use of IT solutions for HR issues

According to our detailed research, we have found that the solutions using artificial intelligence algorithms (Machine Learning, Neural Network, Data Mining) are the most used to solve the HR problems. They oversee the others by a use percentage of $41 \%$, followed by $29 \%$ of other analysis methods or simple statistics, $14 \%$ of BI, Big Data and Data Warehouse solutions then $16 \%$ of simple analysis using software, ERP, frameworks or websites. The Table 2 summarizes the different solutions proposed for each HR problem.

\subsection{Artificial Intelligence Solutions for Human Resources Issues}

Abridged with the acronym AI, it is the science treating the production of the human knowledge, and offering to machines the ability to imitate human reasoning and intelligence. It simulates the execution of tasks similar to those handled by the human being: recognition, prediction, classification, understanding, dialogue, adaptation and learning.

The keyword Artificial Intelligence is quite the buzz in the virtual world in all domains today and since its appearance it has undergone a renaissance in the form of Machine Learning and subsequently the emerging of Deep Learning, which has boomed over the last few years ; thereby giving a new type with deeper examples and algorithms to Machine Learning. Furthermore, we cannot talk about these terms without mentioning the neural networks which represent the core of our research in view of their importance in all substantial items already mentioned. The most known artificial intelligence algorithms used to solve human resources issues as shown in Figure 5. 
Table 2. The IT Solutions for Human Resources Issues

\begin{tabular}{|c|c|c|}
\hline HR Issues & IT Solutions proposed & Publications \\
\hline $\begin{array}{l}\text { Recruitment, } \\
\text { Jobs \& Skills }\end{array}$ & $\begin{array}{l}\text { Job Pruner, Single-label classifier, SVM Linear \& RBF Kernel, RFs, ANNs, LMI Knowledge Graph, } \\
\text { advanced SMA frameworks, SNWs, Cluster analysis, Genetic algorithms, Natural Language }\end{array}$ & {$[17],[25-51]$} \\
\hline Management & $\begin{array}{l}\text { Processing, Speech and Image recognition, Regression Models, Sentiment Analysis, Signal Processing } \\
\text { and Data Visualization, web scraping, Structural equation modeling (MSEM)/ Mplus software, AMO } \\
\text { model, Access, SAP,IBM SPSS, Oracle, R, SAS, Visier Workforce Analytics, SharePoint, Workday, } \\
\text { Excel, Big Data, Fuzzy Analytic Hierarchy Process (FAHP), Grey Relational Analysis (GRA), } \\
\text { Centroid method, Fuzzy VIKOR method, Jobvite, Data Mining, C4.5 DTs, C 5.0 DTs, LDA, Tree J48, } \\
\text { The stepwise weight assessment ratio analysis (SWARA), grey additive ratio assessment (ARAS-G), } \\
\text { Multicriteria Decision-Making (MCDM), Grey Relational Analysis (GRA), Multi Criteria Decision } \\
\text { Making (MCDM), ANCOVA, Naive Bayesian, BI, Social Recruiting (SR) technologies, On-line } \\
\text { Evolute Helix application, Clusters, Rotation Forest, Mapping HR-Analytics-Strategy, Return on } \\
\text { Investment ROI of HR Analytics, Giant Oracle, Online Analytical Processing (OLAP), Technology } \\
\text { Acceptance Model (TAM), Standard Process for Data Mining (CRISP-DM), Waikato tool } \\
\text { Environment for Knowledge Analysis (WEKA), Bayes Net, JRIP, MCDM, Web } 2.0 \text { technologies, } \\
\text { Fuzzy Expert System (FES), Affinity Propagation, }\end{array}$ & \\
\hline $\begin{array}{l}\text { Employee } \\
\text { Attrition } \\
\text { Prediction }\end{array}$ & $\begin{array}{l}\text { RFs, SVMs, KNNs, ANNs, DTs(C5.0, C4.5, REPTree,), Logistic Regression(Logit and Probit model), } \\
\text { CART, discriminant analysis, CART, Naïve Bayes, Rstudio, WEKA data mining tool, C4.5(J48), } \\
\text { REPTree, CART (SimpleCart) decision tree, logistic regression, neural network, SEMMA } \\
\text { methodology, subset selection method, Taguchi method and Nearest Neighbour Classification, particle } \\
\text { swarm optimization, Data Mining, }\end{array}$ & [14-18], [52] \\
\hline $\begin{array}{l}\text { Employee's } \\
\text { Turn Over }\end{array}$ & $\begin{array}{l}\text { DTs, RFs, SVM, MLP, KNN, Naïve Bayes, Sequential Backward Selection Algorithm (SBS), } \\
\text { Decision Tree, Gradient Boosting Trees, Logistic Regression, Linear Discriminant Analysis, } \\
\text { Polynomial Regressions, Cross-Classified Multilevel Analysis, MLP, Python, SPSS, weighted least } \\
\text { squares (WLS), Linear Discriminant Analysis (LDA), Conditional semi-Markov (CSMK) model, self- } \\
\text { organizing maps (SSOM), Extreme Gradient Boosting (XGBoost), dynamic regression, C4.5 Decision } \\
\text { Tree, SPSS } 12.0 \text { software package, Cronbach's a and confirmatory factor analysis, Pearson's } \\
\text { correlation, ANOVA and Scheffe's post hoc analysis, Taguchi Methods, Leader-Member Exchange } \\
\text { (LMX) scale, the Minnesota Satisfaction Questionnaire (MSQ) }\end{array}$ & {$[20,21,[53-69]$} \\
\hline $\begin{array}{l}\text { Improve } \\
\text { human } \\
\text { resources } \\
\text { talents, } \\
\text { productivity, } \\
\text { effectiveness } \\
\text { and } \\
\text { performance }\end{array}$ & $\begin{array}{l}\text { Multiple Criteria Decision-Making (MCDM), Analytical Hierarchy Process (AHP), iThink software, } \\
\text { Back Propagation, HR predictive analytics (HRPA), Structural Equation Modelling (SEM), neuro- } \\
\text { fuzzy approach, Data warehouse, ETL framework, CSV,CSVQL, BI, Data Mining: C4.5 classifier, } \\
\text { J48, KNN, Apriori algorithms, Decision Tree, Random Forest, Neural Network (Multilayer } \\
\text { Perceptron, Radial Basis function), Nearest Neighbor, Logistic Regression, SEMMA SAS, Global } \\
\text { Business Services (GBS), Oracle Fusion Workforce Predictions, PricewaterhouseCoopers Human } \\
\text { Resource System(PWC-HRS), k-means, Simple Addictive Weighting (SAW), Tahani fuzzy, Human } \\
\text { Resource Information System HRIS, Knowledge Discovery in Database KDD, Intelligent Decision, } \\
\text { Apriori algorithm, Support System (IDSS), Fuzzy Hybrid Multicriteria Decision-Making (MCDM), } \\
\text { worst-case method, Modified Fuzzy VIKOR, Text Mining, Bayesian, Sequential Minimal } \\
\text { Optimization (SMO), Neural Networks tools from Matlab, Backpropagation,),SVM, human capital } \\
\text { management (HCM) software, Basic data analysis(Mean,Median Minimum \& maximum range, } \\
\text { Percentiles), Intermediate data analysis (Correlation, Statistically significant differences, Standard } \\
\text { deviation), Basic multivariate models (ANOVA / ANCOVA, Regression, Factor analysis), Advanced } \\
\text { multivariate models (Structural equations models, Hierarchical linear models, Bivariate / multivariate } \\
\text { choice models, Cross level models, including adjustments for grouped and non normal errors ), BI, } \\
\text { Knowledge Discovery in Database (KDD), Intelligent Decision Support System (IDSS) }\end{array}$ & [70-99] \\
\hline
\end{tabular}

It is deduced that the search for IT solutions for HR issues are increasingly developing. Scientists have proposed different solutions to solve these HR problems. Artificial intelligence is not the exception. It also offers different algorithms and methods.

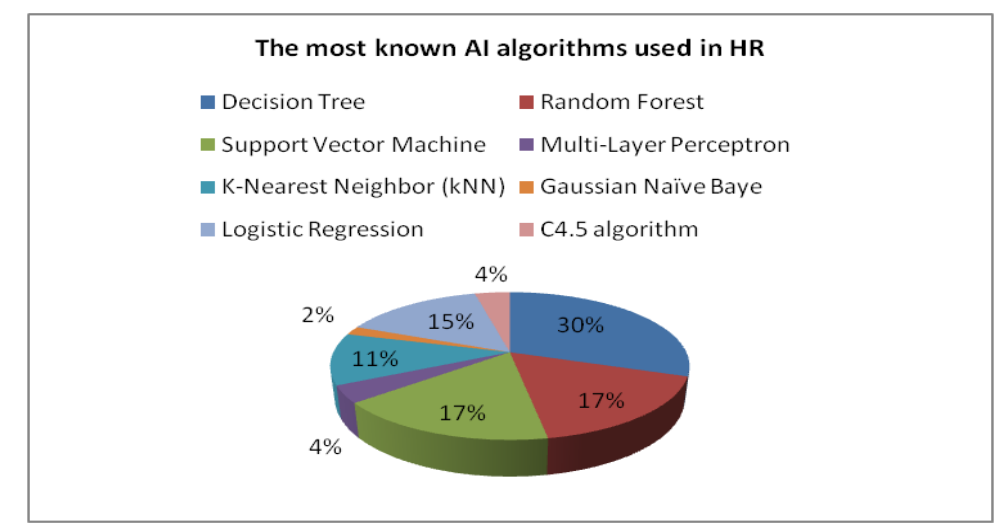

Figure 5. The most known artificial intelligence algorithms used to solve human resources issues 
According to our quantitative research, several IT solutions have been proposed to solve the various problems related to human resources. Many Artificial Intelligence solutions have been applied, using different methods and algorithms. The most known Artificial Intelligence algorithms that have been used are: Decision Tree, Random Forest, Support Vector Machine, Multi-Layer Perceptron, K-Nearest Neighbor (KNN), Gaussian Naïve Baye, Logistic Regression, C4.5 algorithm... etc.

The most used Artificial Intelligence algorithm is Decision Tree with $30 \%$ of use, $17 \%$ using SVM and Random Forest, 15\% for Logistic Regression followed by $11 \%$ for KNN, 4\% MPL and C 4.5 and the less used are Naïve Bayes with percentage of use $2 \%$.

\section{CONCLUSION}

From our research on the two axes : Human Resources and Artificial Intelligence, we were able, first of all, to highlight the different issues raised by the experts and the managers of the domain and to target the most posed problems, afterwards. We have tried to find all the solutions proposed by scientists and computer scientists for each problem and especially those using Artificial Intelligence techniques for the period between 2008 and 2018. We concluded from the number of articles found that several HR Analytics were proposed and most of them used artificial intelligence algorithms and methods, which shows the rapid and observed development and the increased interest and competition in applying this technology in HR field.

The most HR issues asked were about analyzing and predicting: Recruitment, Skills Management, Human Resources Development (employees talents, effectiveness, productivity and performance), attritions and turnover. Proposed solutions were concerning known technologies like Business Intelligence, Big Data, Data Mining \& Data Warehouse, some known software, frameworks and ERP (SAP, SPSS, Oracle, SAS, CRM, SMA, SNW) and Artificial Intelligence algorithms(Machine Learning, Neural Network, Deep Learning...), others used or proposed other analysis methods and simple statistics combined with HR analysis and HR approaches. The most Artificial Intelligence algorithms known used were: Decision Tree (DT), Random Forest (RF), Support Vector Machine (SVM), Multi-Layer Perceptron (MLP), K-Nearest Neighbor (KNN), Gaussian Naïve Bayes (GNB), Logistic Regression (LR), C4.5.

The field of Human Resources is vast and constantly developing. The concern of each company is the management of its Human Resources by considering human capital the source of development and the pillar of success to increase productivity, attract talent and the customers in order to well cope with the competition. On the other hand, the field of intelligence is always evolving and new approaches and methods are always proposed.

\section{REFERENCES}

[1] Bernard Marr. "The 8 HR Analytics Every Manager Should Know About”. Forbes. Mar 1, 2016.

[2] Bernard Marr. "The 18 Best Analytics Tools Every Business Manager Should Know". Forbes. Feb 4, 2016.

[3] R.S. Michalski, J.G. Carbonell, T.M. Mitchell. "Machine Learning: An Artificial Intelligence Approach". 2013.

[4] Norhaslinda Kamaruddin, Abdul Wahab Abdul Rahman, Ramizah Amirah Mohd Lawi. "Jobseeker-industry matching system using automated keyword selection and visualization approach". Indonesian Journal of Electrical Engineering and Computer Science (IJEECS). 2018.

[5] John Bratton, "Jeff Gold. Human Resource Management", 6th Edition: Theory and Practice, 1 Mar. 2017.

[6] Maxime Comptier. "Les Ressources Humaines plus humaines grâce à l'Intelligence Artificielle”. Octopeek. 2018.

[7] Bernard Gauvignon. "Logiciel De Gestion Des Talents Et Intelligence Artificielle". Focus RH. Logiciels RH.

[8] Shoko Haneda \&Keiko Ito. "Organizational and human resource management and innovation: Which management practices are linked to product and/or process innovation? ”, February 2018.

[9] Ashok K. Gupta \& Arvind Singhal. "Managing Human Resources for Innovation and Creativity”, 27 Jan 2016.

[10] Romain Giry. "Intelligence Artificielle : Quelles Applications Pour Les Rh ?", Focus Rh. Erp/Sirh. May 2017.

[11] Sabine Germain, "Gestion Des Risques : Les Ressources Humaines Trop Peu Prises En Compte Par Les Risks Managers. Entreprise \& Carrières". Novembre 2014.

[12] Nicolas DUFOUR et abdel BENCHEIKH. "Comprendre les risques ressources humaines", véritable enjeu et création de valeur pour l'entreprise. 2017.

[13] Porter, Lyman W., Steers, Richard M. ”Organizational, work, and personal factors in employee turnover and absenteeism". Psychological Bulletin. 2016.

[14] Rahul Yedida, Rahul Reddy, Rakshit Vahi, Rahul Jana, Abhilash GV, Deepti Kulkarni. "Employee Attrition Prediction". 02 November 2018.

[15] Jessica Frierson, Dong SiEmai. "Who's Next: Evaluating Attrition with Machine Learning Algorithms and Survival Analysis?", International Conference on Big Data. 21 June 2018.

[16] Devesh Kumar Srivastava, Priyanka Nair. "Employee Attrition Analysis Using Predictive Techniques". ICTIS 2017: Information and Communication Technology for Intelligent Systems. 
[17] K. M. Suceendran, R. Saravanan, Divya Ananthram, Dr.S.Poonkuzhali, R.Kishore Kumar, Dr.K.Sarukesi. “Applying Classifier Algorithms to Organizational Memory to Build An Attrition Predictor Model”. Advances In Information Science And Computer Engineering. 2015.

[18] Alao D. \& Adeyemo A. B. "Analyzing Employee Attrition Using Decision Tree Algorithms". Computing, Information Systems \& Development Informatics Vol. 4 No. 1 March, 2013.

[19] Emmanuel Nwahanye. "Le rôle médiateur de la satisfaction au travail dans le lien entre l'intensité de la gestion des ressources humaines et le roulement du personnel", Septembre 2016.

[20] Ismatilla T. Mardanov, Kenneth Heischmidt, Amy Henson. "Leader-Member Exchange and Job Satisfaction Bond and Predicted Employee Turnover". Journal of Leadership \& Organizational Studies. 2008.

[21] Yafang Tsai and Shih-Wang Wu. "The Relationships Between Organisational Citizenship Behaviour, Job Satisfaction and Turnover Intention”. Journal of Clinical Nursing. 2010.

[22] Carol Alexander. "Managing Operational Risks with Bayesian Networks". 2003.

[23] JY Saulquin, G Schier. Responsabilité sociale des entreprises et performance. "La Revue des Sciences de Gestion". 2007.

[24] H Savall, V Zardet. "Maîtriser les coûts et les performances cachés: le contrat d'activité périodiquement négociable". Economica. 2010.

[25] Bruno Silva, Marco A.S.Netto, Renato L.F.Cunha. JobPruner: "A machine learning assistant for exploring parameter spaces in HPC applications". Future Generation Computer Systems. June 2018.

[26] Roberto Boselli,Mirko Cesarini,Fabio Mercorio, Mario Mezzanzanica. "Classifying online Job Advertisements through Machine Learning". Future Generation Computer Systems. September 2018.

[27] ClydeW.Holsapple, Shih-Hui Hsiao, Ram Pakath. "Business social media analytics: Characterization and conceptual framework". Decision Support Systems. June 2018.

[28] Andrea De Mauro, Marco Grecob Michele Grimaldi, Paavo Ritala. "Human resources for Big Data professions: A systematic classification of job roles and required skill sets". Information Processing \& Management. September 2018.

[29] Reija Oksanen. "New technology-based recruitment methods". University of Tampere Faculty of Management. 2018.

[30] Delores Alarcon, Angela Villarreal, Anna Waller, Sandra Degrassi, Heather Staples. "Follow Me: the Use of Social Media in Recruitment". Southwest Academy Of Management Proceedings Annual Meeting (Suam 2018 Proceedings). 2018.

[31] William J. Heerman, Natalie Jackson, Christianne L. Roumie, Paul A. Harris,S.Trent Rosenbloom, Jill Pulley, Consuelo H. Wilkins, Neely A. Williamse,David Crenshaw, Cardella Leak, Jon Scherdin, Daniel Muñoz,Justin Bachmann,Russell L. Rothman, Sunil Kripalani. "Recruitment methods for survey research: Findings from the Mid-South Clinical Data Research Network”. Contemporary Clinical Trials. 2017.

[32] Elizabeth C. Alexander, Deanna R. D. Mader, Fred H. Mader. "Using Social Media During the Hiring Process: A Comparison Between Recruiters and Job Seekers". 2017.

[33] Jan Rabcan, Monika Vaclavkova, Rudolf Blasko. "Selection of appropriate candidates for a type position using C4.5 decision tree". International Conference on Information and Digital Technologies (IDT). 2017.

[34] Anca Apatean, Evelyn Szakacs, Magnolia Tilca2. "Machine-Learning Based Application For Staff Recruiting". Acta Technica Napocensis Electronics And Telecommunications. 2017.

[35] Jalil Heidary Dahooie, Elham Beheshti Jazan Abadi, Amir Salar Vanaki, Hamid Reza Firoozfar. "Competencybased IT personnel selection using a hybrid SWARA and ARAS-G methodology". Wiley Periodicals. 2017.

[36] Noor Awanis Muslim,David Dean,David Cohen. "Employee Job Search Motivation Factors: An evidence from Electricity Provider Company in Malaysia". Procedia Economics and Finance. 2016.

[37] Nilsen Kundakc1. Personnel selection with grey relational analysis. "Management Science Letters. Management Science Letters". 2016.

[38] Mariam El Ouirdi, Ivana Pais, Jesse Segers,Asma El Ouirdi. "The relationship between recruiter characteristics and applicant assessment on social media". Computers in Human Behavior.

[39] Bedi Supriaty, Rheo Malani, Oki Dwi Nurhayati. "Design of Information System for Acceptance Selection of Prospective Employees Online Using Tahani Fuzzy Logic Method and Simple Additive Weighting (SAW) ". International Journal of Computing and Informatics (IJCANDI). 2016.

[40] Abdul-Kadar Masum, Loo-See Beh, Abul-Kalam Azad, and Kazi Hoque. "iRecruit : A Function for Recruitment using C4.5 Classification Technique”. The International Arab Journal of Information Technology. 2015.

[41] Sven Laumer,Christian Maier, Andreas Eckhardt. "The impact of business process management and applicant tracking systems on recruiting process performance: an empirical study". Journal of Business Economics. 2015.

[42] Rasim M. Alguliyev, Ramiz M. Aliguliyev, and Rasmiyya S. Mahmudova. "Multicriteria Personnel Selection by the Modified Fuzzy VIKOR Method". The Scientific World Journal. 2015.

[43] Kia Hadji Abootorab Kashi M.P.Adm. (HR), B.P.Adm. ”Determinants and Pre-hire Outcomes of Social Recruiting Technology Adoption and Use". Deakin Univeristy. 2015.

[44] Ari Visa, Jarno Einolander, Hannu Vanharanta. "New Tools to Help in the Recruitment Process". Procedia Manufacturing 6th International Conference on Applied Human Factors and Ergonomics (AHFE 2015) and the Affiliated Conferences, AHFE 2015.

[45] Ciprian-Octavian Truică, Adriana Barnoschi. "Innovating HR Using an Expert System for Recruiting IT Specialists-ESRIT". Journal of Software \& Systems Development. 2015. 
[46] Vinay Shashidhar, Shashank Srikant, Varun Aggarwal. "Learning Models for Personalized Educational Feedback and Job Selection". Proceedings of the 32 nd International Conference on Machine Learning, Lille, France, 2015. JMLR: W\&CP. 2015.

[47] Janneke K.Oostrom, Dimitrivan der Linden, Marise Ph.Born, Henk T.van der Molen. "New technology in personnel selection: How recruiter characteristics affect the adoption of new selection technology". Computers in Human Behavior. 2013.

[48] Akhilesh k. Sharma, Dr. Kamaljit Lakhtaria, Santosh Vishwakarma. "Data Mining Based Predictions for Employees Skill Enhancement Using ProSkill-Improvement Program and Performance Using Classifier Scheme Algorithm". International Journal of Advanced Research in Computer Science.2013.

[49] J.O. Daramola, O.O. Oladipupo and A.G. Musa. "A fuzzy expert system (FES) tool for online personnel recruitments". Int. J. Business Information Systems. 2010.

[50] Qiangwei Wang, Boyang Li, Jinglu Hu. "Feature selection for Human resource selection based on Affinity Propagation and SVM sensitivity analysis." World Congress on Nature \& Biologically Inspired Computing (NaBIC). 2009.

[51] H. Chaudhari, N. Yadav, Y.Shukla. "A predictive analysis on job recruitment". International Conference on Recent Trends in Engineering, Science \& Technology-(ICRTEST 2016).

[52] Dilip Singh Sisodia, Somdutta Vishwakarma, Abinash Pujahari. "Evaluation of machine learning models for employee churn prediction". 2017 International Conference on Inventive Computing and Informatics (ICICI).

[53] Mirza Mohtashim AlamEmail authorKarishma MohiuddinMd, Kabirul IslamMehedi HassanMd, Arshad-Ul HoqueShaikh Muhammad Allayear. "A Machine Learning Approach to Analyze and Reduce Features to a Significant Number for Employee's Turn over Prediction Model". Science and Information Conference SAI 2018: Intelligent Computing.2018.

[54] Sophie De Winne, Elise Marescaux, Luc Sels, Ilke Van Beveren \& Stijn Vanormelingen. "The impact of employee turnover and turnover volatility on labor productivity: a flexible non-linear approach". The International Journal of Human Resource Management. 2018.

[55] Angelika Kornblum, Dana Unger \& Gudela Grote, "When do employees cross boundaries? Individual and contextual determinants of career mobility". European Journal of Work and Organizational Psychology. 2018.

[56] Mari Maisuradze. "Predictive Alaysis On The Example Of Employee Turnover". Tallinn University Of Technology. 2017.

[57] XiomaraDeJesus. "Strategies for Reducing Voluntary Employee Turnover". Walden University, ProQuest Dissertations Publishing. 2017.

[58] Alex L. Rubenstein, Marion B. Eberly, Thomas W. Lee, Terence R. Mitchell. "Surveying the forest: A metaanalysis, moderator investigation, and future-oriented discussion of the antecedents of voluntary employee turnover". Wiley Personnel Psychology. 2017.

[59] Edouard Ribes, Karim Touahri, Benoit Perthame, "Employee turnover prediction and retention policies design: a case Study". Computers and Society. 2017.

[60] Ming Fanga, Jia-Hao Sub, Tao Wangc, and Ren-Jie Hed. "Employee Turnover Prediction Based on State-transition and Semi-Markov-A Case Study of Chinese State-owned Enterprise". The 4th Annual International Conference on Information Technology and Applications (ITA 2017).

[61] Mauricio A.Valle, Gonzalo A.Ruz, Víctor H.Masíasc. "Using self-organizing maps to model turnover of sales agents in a call center". Applied Soft Computing.2017.

[62] Gao Ying. "Using Decision Tree to Analyze the Turnover of Employees". Uppsala University Department of Informatics and Media Information Systems. 2017.

[63] Xiaojuan Zhu, Rapinder Sawhney, Girish Upreti. "Determinates of Employee Voluntary Turnover and Forecasting in R\&D Departments: A Case Study". Studies in Engineering and Technology. 2016.

[64] Xiaojuan Zhu, William Seaver, Rapinder Sawhneya, Shuguang Ji, Bruce Holt, Gurudatt Bhaskar Sanila and Girish Upreti. "Employee turnover forecasting for human resource management based on time series analysis". Journal of Applied Statistics. 2016.

[65] John E. Kobza, James L. Simonton, Russell Zaretzki, "Forecasting Employee Turnover in Large Organizations", University of Tennessee, Knoxville Trace: Tennessee Research and Creative Exchange. 2016.

[66] Xiao-Li QU. "A decision tree applied to the grass-roots staffs' turnover problem-take C-R Group as an example". 2015 IEEE International Conference on Grey Systems and Intelligent Services (GSIS).

[67] Gonzalo A.Ruz, Mauricio A.Valle. "Turnover Prediction in a Call Center: Behavioral Evidence of Loss Aversion using Random Forest and Naïve Bayes Algorithms". Applied Artificial Intelligence An International Journal. 2015.

[68] HSIN-YUN CHANG. "Employee Turnover: A Novel Prediction Solution with Effective Feature Selection". WSEAS Transactions on Information Science and Applications. 2009.

[69] Rohit Punnoose, Pankaj Ajit. "Prediction of Employee Turnover in Organizations using Machine Learning Algorithms". (IJARAI) International Journal of Advanced Research in Artificial Intelligence. 2016.

[70] Hamidah Jantan, Abdul Razak Hamdan, and Zulaiha Ali Othman. "Knowledge Discovery Techniques for Talent Forecasting in Human Resource Application". World Academy of Science, Engineering and Technology International Journal of Industrial and Manufacturing Engineering. 2009.

[71] Jayanthi Ranjan, D.P. Goyal, S.I. Ahson. "Data mining techniques for better decisions in human resource management systems". International Journal of Business Information Systems. 2008.

[72] Mehdi Pariav, Ahad Khalaji, S.Z.Hashemi, Majid Radfard. "Assessment of prioritizing the effective factors on human resources effectiveness (Case study: Tehran Industrial Parks Organization) ”. Data in Brief. August 2018. 
[73] Derrick McIver,MarkL.Lengnick-Hall,CynthiaA.Lengnick-Hall. "A strategic approach to workforce analytics: Integrating science and agility". Business Horizons. May-June 2018.

[74] Mario Andrés Paredes Valverde, María del Pilar Salas-Zárate, Ricardo Colomo-Palacios, Juan Miguel GómezBerbís, Rafael Valencia-García. "An ontology-based approach with which to assign human resources to software projects". Science of Computer Programming. 1 May 2018.

[75] Inmaculada Beltrán-Martín Juan Carlos Bou-Llusar. "Examining the intermediate role of employee abilities, motivation and opportunities to participate in the relationship between HR bundles and employee performance". BRQ Business Research Quarterly. April-June 2018.

[76] Dale L. Lunsford PhD Patti P. Phillips PhD. ”Tools Used by Organizations to Support Human Capital Analytics”. Performance Improvement. 25 March 2018.

[77] Tyrone D. Smith, Jr. "Perceptions of Human Resource Professionals on Using Data Analytics for Talent Management". 8 January 2018.

[78] Yavuz Özdemir, Kemal Gökhan Nalbant, Hüseyin Başligil. "Personnel Selection For Promotion Using An Integrated Fuzzy Analytic Hierarchy Process-Grey Relational Analysis Methodology: A Real Case Study". Anadolu University Journal of Science And Technology A-Applied Sciences And Engineering. 2018.

[79] Richa Das Related, Chandan Bhar. "System dynamics-based approach to manpower planning: a study of Indian microfinance institutions". Int. J. Business Information Systems. 2018.

[80] S. Chitra, Dr. P. Srivaramangai. "A Study on Analytics of Human Resource Management in Big Data". International Journal of Scientific Research in Computer Science, Engineering and Information Technology (IJSRCSEIT). 2018.

[81] Zhibin Lin, Ilias Vlachos. "An advanced analytical framework for improving customer satisfaction: A case of air passengers". Transportation Research Part E: Logistics and Transportation Review. 2018.

[82] Widodo Budiharto, Anggita Dian Cahyani. "Modeling Intelligent Human Resources Systems (IRHS) using Big Data and Support Vector Machine (SVM)". ICMLC 2017 Proceedings of the 9th International Conference on Machine Learning and Computing.

[83] Naimatullah Shah, Zahir Irani, Amir M.Sharif. "Big data in an HR context: Exploring organizational change readiness, employee attitudes and behaviors". Journal of Business Research. 2017.

[84] Mila Lazarova, Hilla Peretz, Yitzhk Fried. "Locals know best? Subsidiary HR autonomy and subsidiary performance". Journal of World Business. 2017.

[85] John T.Delaney, Mark A.Huselid. "The Impact of Human Resource Management Practices on Perceptions of Organizational Performance". Academy of Management Journal. 2017.

[86] Jasmien Lismont, Jan Vanthienen, Bart Baesens, "Wilfried Lemahieu. Defining analytics maturity indicators: A survey approach”. International Journal of Information Management. 2017.

[87] Tomas Chamorro-Premuzic, Reece Akhtar, Dave Winsborough, Ryne ASherman. "The datafication of talent: how technology is advancing the science of human potential at work? Current Opinion in Behavioral Sciences". 2017.

[88] S Van den Heuvel, T Bondarou, "The rise (and fall?) of HR analytics: A study into the future application, value, structure and system support". the 2nd HR Division International Conference(HRIC). 2017.

[89] Vesko Lukovac,Dragan Pamučar, Milena Popović, Boban Đorović. "Portfolio model for analyzing human resources: An approach based on neuro-fuzzy modeling and the simulated annealing algorithm". Expert Systems with Applications. 2017.

[90] Zagross Hadadian, Kimiya Mesbah, "Selecting An Effective Leader- A Competency Based Fuzzy Vikor Analysis Model, Investigación", Ciencia Y Tecnología Institución Universitaria Salazar Y Herrera, Iush. 2017.

[91] Gudivada Venkat Rao, K. Indira Priyadarshini. "Some Insights Into Procedures And Practices To Acquire The Right Talent”. Journal Of Strategic Human Resource Management. 2017.

[92] Sefik Ilkin Serengil, Alper Ozpinar. "Workforce Optimization for Bank Operation Centers: A Machine Learning Approach". International Journal of Interactive Multimedia and Artificial Intelligence. 2017.

[93] Konstantinos Triantos. "Human resources analytics at Viggo warehousing solutions for CSV data. Eindhoven University of Technology", Department of Mathematics and Computer Science Web Engineering Group. 2016.

[94] Shaji A.Khan, Jintong Tang. "The Paradox of Human Resource Analytics: Being Mindful of Employees". Journal of General Management. 2016.

[95] Tom Pape. "Prioritising data items for business analytics: Framework and application to human resources". European Journal of Operational Researc. 2016.

[96] Dr. Seema Swanand Sant. "A study on the HR analytics competitive advantage for organization as a HR strategy". Journal of Advance in Business Management. 2016.

[97] Jensen-Eriksen, Krista. "The role of HR analytics in creating data-driven HRM: Textual network analysis of online blogs of HR professionals". Department of Management Studies Aalto University School of Business. 2016.

[98] Munef Abdullah Ahmed, Raed Abdulkareem Hasan, Ahmed Hussein Ali, Mostafa Abdulghafoor Mohammed. "The classification of the modern arabic poetry using machine learning". TELKOMNIKA (Telecommunication, Computing, Electronics and Control), Vol.17, No.5, October 2019, pp.2667-2674.

[99] Tew Jia Yu, Chin Poo Lee, Kian Ming Lim, Siti Fatimah Abdul Razak. "AI-Based Targeted Advertising System". Indonesian Journal of Electrical Engineering and Computer Science (IJEECS). 2018.

[100] S. Karupiah, M. H. Hussain, I Musirin, S.R.A. Rahim. "Prediction of overcurrent rRelay miscoordination time using artificial neural network". Indonesian Journal of Electrical Engineering and Computer Science (IJEECS). 2018. 